\title{
Evaluation of the quality of Sorbus fruits belonging to different species
}

\author{
Barabits E. ${ }^{1}$, Szabó N. ${ }^{2}$, Sipos B. Z. ${ }^{2}$ and Szenthe A. ${ }^{2}$

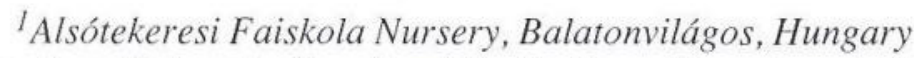 \\ ${ }^{2}$ Budapest Corvinus University Faculty of Horticulture, Department of Fruit Growing
}

\begin{abstract}
Summary: The interest in wild growing fruits was increased considerably by the pharmaceutical industry, the cosmetics as well as by the food industry. (Stefanovits-Bányai et al., 2004). Elderberry (Sambucus nigra L), sand thorn (Hippophaë rhamnoides L.), cornel (Cornus mas L.), dog rose (Rosa canina L. bearing hips) and the Sorbus species (Sorbus ssp.) have been well known medicinal and/or ornamental plants since long. Recently, precious substances have been detected in their fruits, which are indispensable in healthy foods. Several species and micro-species of the genus Sorbus are components of the native flora of Hungary, and the fruit of some of them have been consumed traditionally, however, they are preferably considered as ornamentals. The nursery of Alsótekeres (Balatonvilágos) maintained some 16 clones of Sorbus species, which are mainly apomictic "micro species" of the collection. In 2003, a comprehensive analysis of sorb fruits born on apomictic micro species was initiated in order to find those, which will be suitable to establish plantations. It turned out that considerable differences exist between the fruits of individual taxa, however, it is largely influenced by seasonal effects. According to physical measurements, a scale of mean fruit masses could be established. As for chemical ingredients of the fruits, those are of special interest, which are involved mainly in anti-oxidant activities of the organisms (calcium, potash, phosphorus, copper, magnesium).
\end{abstract}

Key words: Sorbus, growing, anti-oxidants, chemical analysis

\section{Introduction}

Recently, an increasing number of wild growing fruit bearing trees have been cultivated and utilised in the food industry of Hungary (black elder, sand thorn, rose hip, cornel). The fruit of those species contain considerable quantities of vitamins, minerals, colouring substances as well as anti-oxidants and/or radicle-capturing substances. Food science considers those compounds to be biologically active substances.

The indicated fruit species have been known and utilised for thousands of years in popular medicine, however, intrinsic determination of the active ingredients and relevant processes took place only recently. The chemical composition proved to be especially precious because of the many times higher concentration of important elements than in traditionally grown fruits.

The genus Sorbus is commonly known as a complicated taxonomical unit. It belongs to the Maloideae subfamily of the Rosaceae family, which is spreaded throughout the northern hemisphere, comprises many genera of highly variable species, where the number of forms and varieties is enhanced by the abundance of spontaneous inter-specific hybrids.

The European Sorbus species of the genus are assigned to five subgenera. Four of the subgenera contain one single species as the dwarf medlar or whitebeam of higher elevations (Sorbus chamaemespilus), the rowan or mountain ash (Sorbus aucuparia), the domestic service tree (Sorbus domestica) and the wild service tree (Sorbus torminalis). The fifth, aria sub-genus of the genus Sorbus contains several species and intermediate forms, e.g. the whitebeam (Sorbus aria), the Greek whitebeam (Sorbus graeca) and the Austrian whitebeam (Sorbus austriaca).

The sorbs are deciduous trees or shrubs with entire, lobed or pinnate leaves of alternate phyllotaxis. The buds are large, tightly covered by scales. The stipules are conspicuous but deciduous. One part of the leaf petiole remains on the leaf base. The inflorescences are densely composed, corymb-like panicles. The fruits are of variable size, apple-type structure. Their colour is either vivid (red, yellow, brown or ivory) or often dull brown with lenticelles. The meat of the fruit is mealy and hard until ripening, then becomes soft sometimes like a marmalade. The wall of the follicles is usually skinny or stony and contain one or two seeds per fruit.

The energy content of the fruits is generally low 117-247 kJ/100g - but the fruit of the service tree ( $S$. domestica) is similar to apple (Stoll \& Gremminger, 1986), but compared with apple the energy content may be significantly higher (Bíró \& Lindner, 2003) i.e. $410 \mathrm{~kJ} / 100 \mathrm{~g}$.

Carotene content is $2.4 \mathrm{mg} / 100 \mathrm{~g}$, which is outstanding in relation to the fruits consumed generally: apricots $1.8 \mathrm{mg} / 100$ $\mathrm{g}$, apple $0.05 \mathrm{mg} / 100 \mathrm{~g}$.

The content of $\mathrm{C}$ vitamin of fruits is also considerable $(120-150 \mathrm{~g} / 100 \mathrm{~g})$, it approaches that of black currants (160 $\mathrm{g} / 100 \mathrm{~g}$ ) and some other wild grown fruits (dog rose hip, sand 
thorn). In Sorbus fruits, some of the mineral elements are outstanding in relation to apples (calcium, potash, phosphorus, copper, magnesium), moreover, they contain also much more iron.

In the end we should also mentioned that all Sorbus species are important inoculum sources of fire blight caused by Erwinia amylovora, which causes severe yield loss of Hungarian pear and apple orchards (Holb, 2005).

Table 1. Chemical composition of Sorbus and apple fruits expressed in $100 \mathrm{~g}$

(Stoll \& Gremminger, 1986; Bíró \& Lindner, 2003)

\begin{tabular}{|l|c|c|}
\hline Composition & Sorbus & Apple \\
\hline Energy (kJ/kcal) & $410 / 98$ & $131 / 31$ \\
Protein (g) & 1.2 & 0.4 \\
Acids (g) & 2.3 & 0.4 \\
Carbohydrate (g) & 22.9 & 7 \\
Water (g) & 73 & 90.5 \\
Crude fibres (g) & 3.2 & 1.3 \\
Carotene (mg) & 2.4 & 0.05 \\
Ascorbic acid (mg) & $120-150$ & 5 \\
K (mg) & 234 & 112 \\
Ca (mg) & 42 & 5.5 \\
Mg (mg) & 17 & 6 \\
Fe (mg) & 2.0 & 0.3 \\
P (mg) & 33 & 8 \\
\hline
\end{tabular}

\section{General characterisation of some Sorbus micro-species examined}

\section{Mountain ash or rowan (Sorbus aucuparia)}

It is a member of the European flora, from the shores of the Atlantic Ocean until the Caucasus and the Ural mountains. In Hungary, we find it in higher altitudes of the mountains and in the western Transdanubian forests. Soils of low nutrient content as well as acidic reaction are also suitable growing sites (Grau \& Münker 1983).

The trees grow to $10-12 \mathrm{~m}$ with a loose crown. The pinnate leaves remind of Robinia. The inflorescences are large, flat corymbs blooming during May and June. Fruits are round, their diameter being about $1 \mathrm{~cm}$, cinnabar red and taste tartish. They are not consumed as fresh fruit rough, but are being processed as juice or syrup. The ripening period is September, but fruits are maintained on the trees throughout the winter offering food for birds.

Mountain ash is well known also as a medicinal plant, and its use is manifold.

The fruit (Sorbi fructus) is suitable for supplying vitamin $\mathrm{C}$, and other ingredients, sorbin, parasorbic acid, malic acid, sugar, wax, anthocyanines (Grau \& Münker, 1983).

Leaves (Sorbi folii), flowers (Sorbi flos), fruits (Sorbi fructus) are well known drugs. Dried leaves may substitute tea (Theae folium).

We have to mention also the content of malic acid, tannin, pectin, carotene, amygdaline and cyano-glycosids (Szalay \& Halmágyi, 1998.).

\section{Whitebeam (Sorbus aria)}

In Hungary and in Europe, it is a common species.

Requires much light, thus as a forest tree it occurs in scattered oak-, lime-, ash-forests of rocky growing sites, wood edges. The soil may be a thin layer of stony loam, almost always containing lime (Grau, Jung \& Münker, 1983), Barabits (2003) stated that the species has high tolerance to drought.

The tree or shrub grows up to $5-15 \mathrm{~m}$ and rather broad, cylindrical. The oval leaves are glossy deep green, their abaxial side is woolly white. The fruits are oval, $12-15 \mathrm{~mm}$ long. Ripe in September, they are first orange red turning deep scarlet with white dots. The fruit meat is yellowish white, mealy and taste tartish (Gencsi \& Vancsura, 1992 in Tátraházi, 2002).

\section{Wild service tree (Sorbus torminalis)}

It occurs from Northern Africa, through Europe until Asia Minor. Except on the plains, we may meet it in Hungary in the mountains and in southern Transdanubia everywhere, in hornbeam-oak forests, talus slopes and narrow gorges (Kézdy, 1995).

The truncated cone shaped or irregularly round crown bears lobed leaves, which turn red before leaf shedding, being of special value as for an ornamental. Its blooming time is a little later than that of the other species in May. Fruits are $12-15 \mathrm{~mm}$ long, first reddish yellow turning to brown with white dots. The ripe fruits contain sclerotic granules, and the meat becomes soft and is comestible. Its drought tolerance is unique (Barabits, 2003).

Further advantage of the species is its graft-compatibility with pear and hawthorn too.

\section{Transylvanian sorb (Sorbus dacica)}

Tree or less frequently shrub with an oval shaped crown. The lobes of the leaves are shorter than a quarter of the width of the blade. Its drought tolerance is intermediate.

\section{Dégen's sorb (Sorbus degenii)}

Its area is the medium dry shrubby forests and northern, grassy slopes of the Vértes mountains, a part of the Hungarian central mountains. Its appearance and size is near to that of the related species, S. torminalis, and so its tolerance and value as an ornamental is also similar.

Leaves and fruits are also comparable with S. torminalis, the lobes of leaves are, however, less marked. The abaxial surface of leaves is somewhat hairy, gray-green until the end of the summer. Autumn discoloration of the canopy is brown. In Transylvania, it occurs under extremely dry conditions on rocky slopes as a small tree or shrub (Barabits, 2003). 


\section{Material and method}

In the nursery of Alsótekeres there is a collection of Sorbus accessions of Hungarian as well as of foreign origin. Among those, some 16 apomictic micro-species have been measured and analysed chemically in 2003. Four of them (number $2,3,5,14$ ) did not bear enough fruit for sampling, therefore they are not included in the results (Table 2 presents the micro-species and the relevant abbreviations applied in the Figures).

Table 2. The list of the Sorbus species examined and their abbreviations applied

\begin{tabular}{|c|c|c|}
\hline Number & Species and authors & Abbreviations applied \\
\hline 1. & S. aucuparia (L.) 'Golden Wonder' & S. arn. G.W. \\
\hline 2. & S. aucuparia (L.) var. edulis (DIECK.) & S. edulis \\
\hline 3. & S. aucuparia Typ. Schmidt & S. Schmidt \\
\hline 4. & S. dacica (BORB.) & S. dacica \\
\hline 5. & S. hybrida (L.) syn. S. fennica & S. hybrida \\
\hline 6. & S. andreánszkyana (KÁRP.) & S. andr. \\
\hline 7. & S. sp. Nova 'Kapolnadomb' & S. Káp. \\
\hline 8. & S. barthae (KÁRP.) & S. barthae \\
\hline 9. & S. bakonyensis (JÁV. em. KÁRP.) & S. bak. \\
\hline 10. & S. vértesensis (BOROS) & $\mathrm{S}$, vért. \\
\hline 11. & S. adamii (KÁRP.) & S. adamii \\
\hline 12. & S. pseudobakonyensis (KÁRP.) & S. ps.bak. \\
\hline 13. & S. pseudolatifolia (BOROS) & S. ps.lat. \\
\hline 14. & S. degenii (JÁV.) & S. degenii \\
\hline 15. & S. borosiana (KÁRP.)'Alba Regia' & S. alb.reg. \\
\hline 16. & S. decipientiformis (KÁRP.) 'Vallus' & S. dec. Vall. \\
\hline
\end{tabular}

The nursery is located near the highway $\mathrm{M} 7$, at a distance of $100 \mathrm{~km} \mathrm{SW}$ from Budapest, on the western margin of Mezőföld (a major agricultural area with little vertical articulation). The soil is chernozem on loess with high lime content $(\mathrm{pH}<8)$. The dry, sunny area is watered from Lake Balaton by pipes.

The trees were grown as grafts on Sorbus intermedia rootstock, and planted in 1998 at a distance of $3 \mathrm{~m} \times 1.5 \mathrm{~m}$. No pruning was practised. The rows were cultivated mechanically, and the base of trees protected, temporarily, by ridges. No chemical treatment was applied.

The measured fruit parameters were the length, diameter and weight $(g / 10)$. Analyses were performed at the laboratory of the Corvinus University of Budapest, Faculty of Horticulture, Department of Fruit Growing. Tests requiring more technical equipment were done at the Chemical and Biochemical Departments of the Faculty of Food Sciences.

The experimental study of fresh fruits determined the physiologically as well as food-technologically significant compounds by the following characters and methods:

- Dry matter content (\%) according to the standard: MSZ 2429-1980.

- Determination of the anti-oxidant - capacity $(\mu \mathrm{M}$ $\mathrm{AS} / \mathrm{ml}$ ): spectrophotometric procedure according to Benzie \& Strain (1996) at $\lambda=593 \mathrm{~nm}$.

- Determination of minerals $(\mu \mathrm{g} / \mathrm{g})$ : by a CP-OES Thermo Jarrel device.
All analyses of chemical composition were performed twice, and the means of the results are published. In expressing the anti-oxidant capacity, ascorbic acid was considered as a standard.

\section{Results}

\section{The variability of fruit mass}

As for the size of fruits, the "species of large fruit" are to be distinguished because the appearance of the canned produce is the most important moment. In this respect, the sequence is the following: Sorbus pseudolatifolia (Figure 1), then Sorbus pseudobakonyensis, Sorbus decipientiformis 'Vallus', and Sorbus degenii. Taxa between S. ancuparia Typ Schmidt and S. ancuparia varr. edulis have especially small fruits, whereas the eight species between Sorbus bakonyensis and Sorbus borosiana 'Alba Regia' are intermediate.

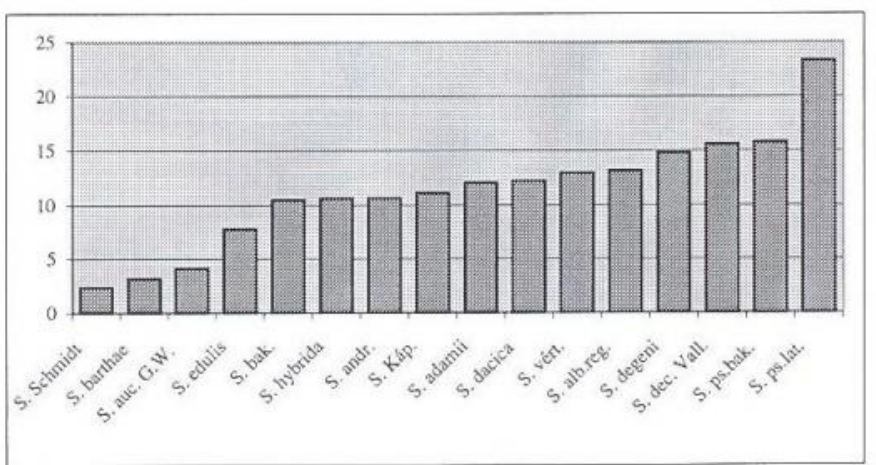

Figure 1 Micro species of the Sorbus genus according to their mass of fruits $(\mathrm{g} / 10 \mathrm{pc})$ (Alsótekeres 2003)

\section{The dry matter content of Sorbus fruits}

The dry matter content of fruits is an essential character from the point of view of fresh consumption as well as of the technology of processing. The types examined are all outstanding from the point of view of dry matter content, which is a precious trait. According to Figure 2, the highest values are found in Sorbus dacica $(49.9 \%)$, whereas the lowest $(28.9 \%)$ in Sorbus vertesensis. The rest of taxa were intermediate as regard dry matter content.

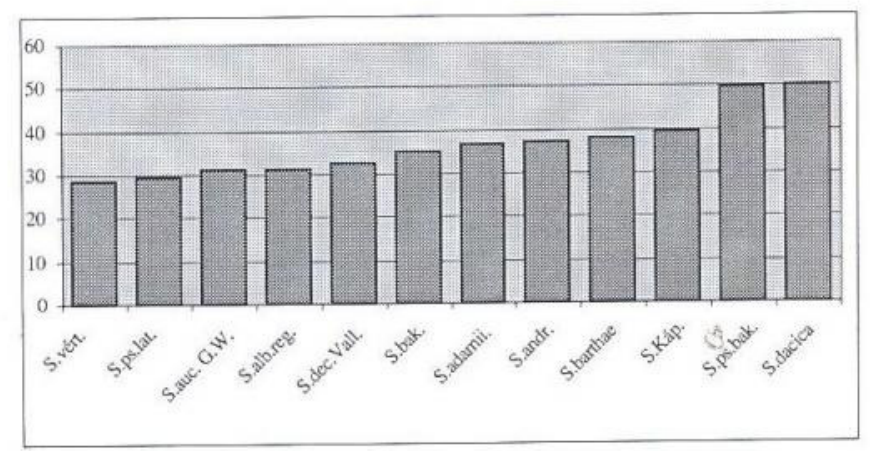

Figure 2 The dry matter content (\%) of fruits of Sorbus micro species (Alsótekeres, 2003) 


\section{Anti-oxidant capacity of fruits}

The importance of this trait is in its use from the point of view of health care. Free redicles have to be bound and prevented from becoming harmful in the organism, because they initiate malignant processes, which have to be stopped or interrupted by anti-oxidant substances.

As for the anti-oxidant capacity of the taxa, significant differences are detected (Figure 3).

In 2003 , Sorbus adamii $(2.9 \mu \mathrm{m} \mathrm{AS} / \mathrm{ml})$ proved to be the best, whereas Sorbus dacica $(0.91 \mu \mathrm{m} \mathrm{AS} / \mathrm{ml})$ produced the lowest values of anti-oxidant capacity. It should be noted that according to the data of Szabó et al. (2004) the values above $2 \mu \mathrm{m} \mathrm{AS} / \mathrm{ml}$ of anti-oxidant capacity are competitive with the best black elder samples.

\section{Calcium content of fruits}

The data presented in Figure 4 compared with those of other fruit species (Biró \& Lindner, 2003) proved that the calcium content in fruits of Sorbus micro species is surpassed by some shelled fruits (nut and hazel) only. Other "soft" fruits contain much less calcium than Sorbus fruits. The lowest calcium content was found in Sorbus pseudolatifolia $(1776 \mu \mathrm{g} / \mathrm{g})$ out of the 12 micro species, whereas Sorbus barthae excelled with $2717.5 \mu \mathrm{g} / \mathrm{g}$.

\section{Potash content of fruits}

In Figure 5, results of the analyses performed in 2003 show the lowest value of potash content in Sorbus sp. nova

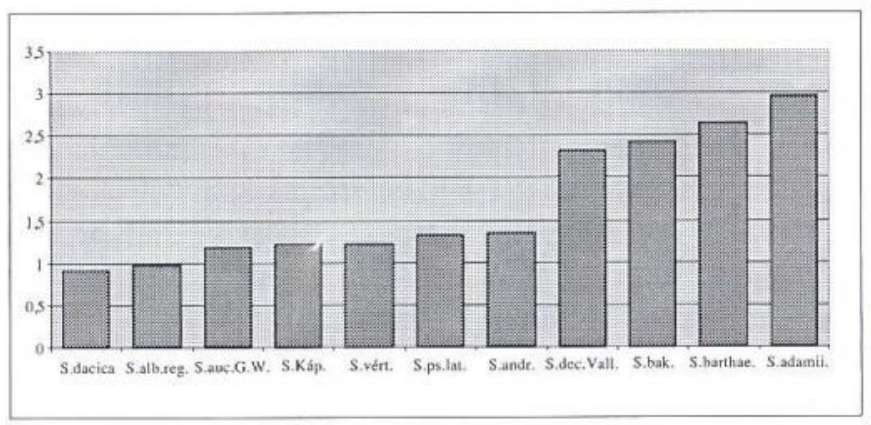

Figure 3 Anti-oxidant capacity of fruits of Sorbus micro species ( $\mu \mathrm{m}$ AS/ml) (Alsótekeres, 2003)

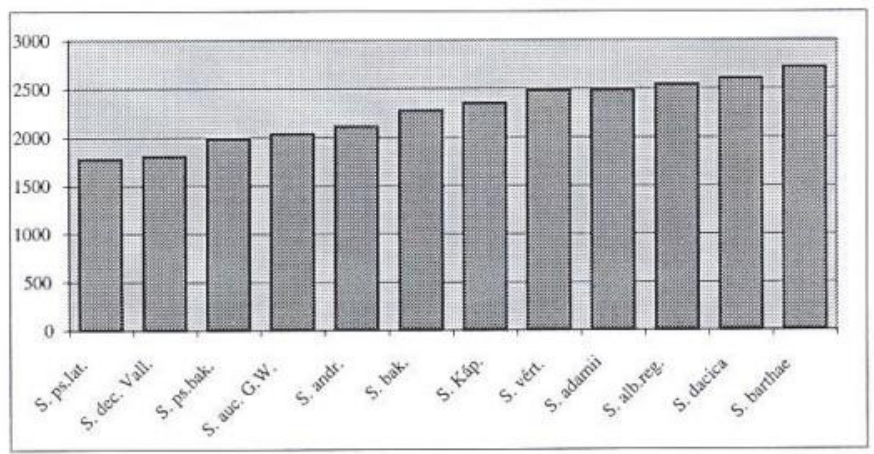

Figure 4 Calcium content of fruits of Sorbus micro species $(\mu \mathrm{g} / \mathrm{g})$ (Alsótekeres, 2003)
'Kápolnadomb' (5665 $\mathrm{g} / \mathrm{g})$, whereas Sorbus dacica had the highest value $(9294.5 \mu \mathrm{g} / \mathrm{g})$. Those values are outstanding similarly to the calcium content. The first four items are surpassed only by walnut with 17100 according to Biró \& Lindner (2003).

\section{Magnesium content of fruits}

The results of 2003 are presented in Figure 6, where the lowest magnesium content was found in Sorbus bakonyensis (971.6 $\mu \mathrm{g} / \mathrm{g})$, whereas the highest in Sorbus borosiana 'Alba Regia' $(1637 \mu \mathrm{g} / \mathrm{g})$. According to the earlier cited literature, more magnesium was found among 24 fruits species only in walnut, almond and hazel.

\section{Phosphorus content of fruits}

The lowest phosphorus content, $417.5 \mu \mathrm{g} / \mathrm{g}$ was measured in fruits of Sorbus bakonyensis and the rest of the samples showed gradually increasing figures up to Sorbus adamii $(807.4 \mu \mathrm{g} / \mathrm{g})$ with the highest value (Figure 7 ).

\section{Copper content of fruits}

In Figure 8, it is evident that almost threefold differences of copper content are found within the series of micro species. The highest values are represented by Sorbus pseudolatifolia $(8.736 \mu \mathrm{g} / \mathrm{g})$, whereas Sorbus borosiana 'Alba Regia' was at the end of the list $(3.21 \mu \mathrm{g} / \mathrm{g})$. Compared with the data of Biró \& Lindner (2003), it is surprising that Sorbus samples contain much more copper than other fruits

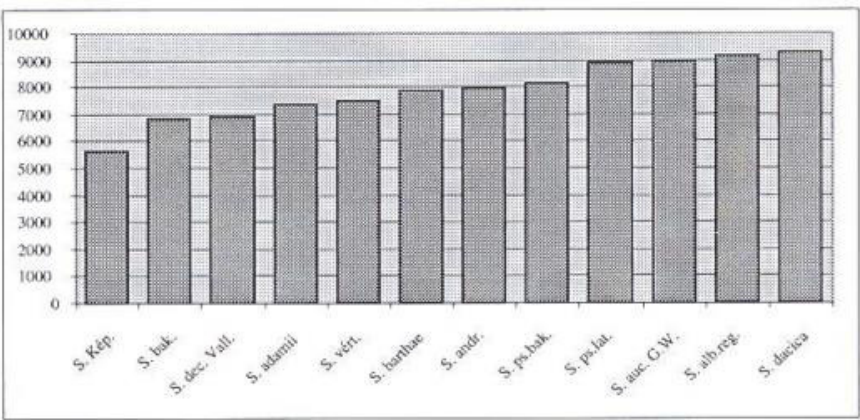

Figure 5 Potash content of fruits of Sorbus micro species $(\mu \mathrm{g} / \mathrm{g})$ (Alsótekeres, 2003)

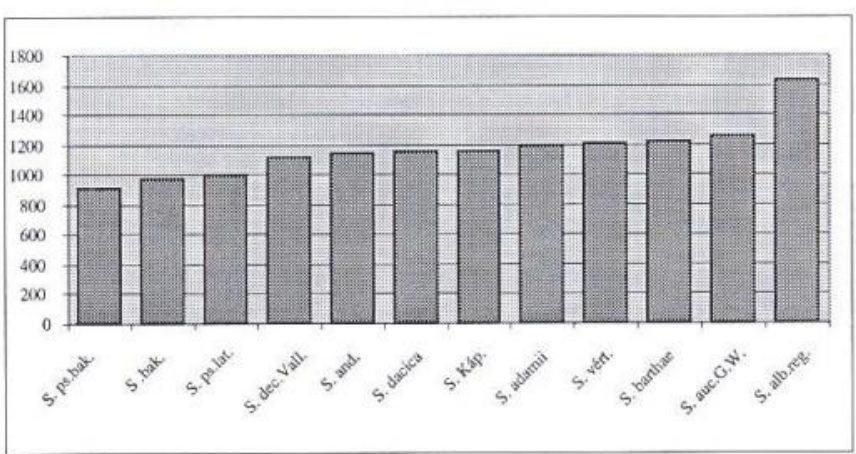

Figure 6 Magnesium content of fruits of Sorbus micro species $(\mu \mathrm{g} / \mathrm{g})$ (Alsótekeres, 2003) 


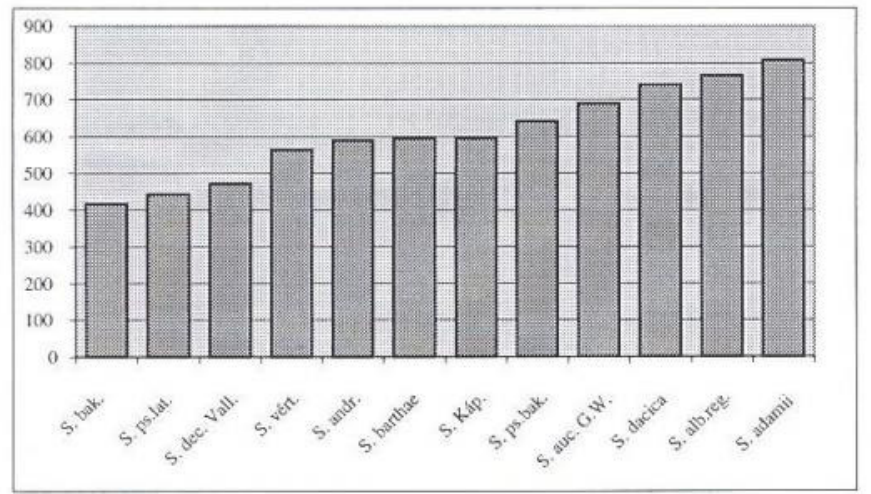

Figure 7 Phosphorus content of fruits of Sorbus micro species $(\mu \mathrm{g} / \mathrm{g})$ (Alsótekeres, 2003)

except hazel $(11.0 \mu \mathrm{g} / \mathrm{g})$, walnut $(8.6 \mu \mathrm{g} / \mathrm{g})$ and almond $(8.1 \mu \mathrm{g} / \mathrm{g})$.

\section{References}

Barabits E. (2003): A berkenyék értékei. Elốadás, OMMI Tordasi Állomása

Bíró Gy. \& Lindner K. (1999): Tápanyagtáblázat. Medicina Könyvkiadó, Budapest.

Bíró Gy. \& Lindner K. (2003): A gyümölcsök ásványianyagtartalma. In: Papp J. (ed.): Gyümölcstermesztési alapismeretek. Mezógazda Kiadó, Budapest

Eder R. (1993): Selektion, Anbau und Verarbeitung der Eberesche mit besonderer Berücksichtigung der Inhaltsstoffe. In: Albrecht, HJ (ed): Anbau und Verwertung von Wildobst. Bernard Thalacker Verlag GmbH \& Co. KG Braunschweig.

Grau J. \& Münker M. (1983): Beeren, Wildgemüse, Heilkrauter. Mosaik Verlag GmbH, München.

Holb I. (2005): Túzelhalás - Erwinia amylovora. 145-150. In: Holb I (szerk.): A gyümölcsösök és a szőlő ökológiai növényvédelme. Mezôgazda Kiadó, Budapest

Hrotkó K., Végváry Gy., Nádosy F. \& Fodor P. (1992): A Sorbus domestica L. gyümölcsmorfológiája és beltartalmi értéke. A „Lippay János” tudományos ülésszak előadásai és poszterei,

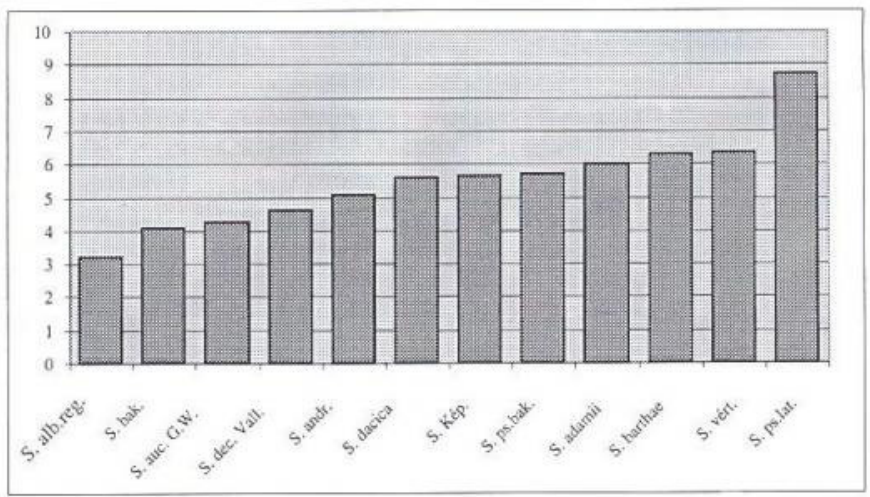

Figure 8 Copper content of fruits of Sorbus micro species $(\mu \mathrm{g} / \mathrm{g}$ ) (Alsótekeres, 2003)

Kertészet, I. kötet, Kertészeti és Élelmiszeripari Egyetem, Budapest, 17.

Kézdy P. (1995): Elfelejtett fafajaink: a berkenyék. Erdészeti Lapok. 130 (7-8): 232-234.

Nádosy F., Végváry Gy. \& Hrotkó K. (1993): Eredeti íz a múltból. Kertészet és Szólészet. 3: 16-17.

Nagy B. \& Schmidt G. (1991): Kertészeti dendrológia. Kertészeti és Élelmiszeripari Egyetem, Budapest.

Soó R. (1966): A magyar flóra és vegetáció rendszertaninövényföldrajzi kézikönyve II. Akadémiai Kiadó, Budapest.

Stefanovits-Bányai É., Schiffler E., Stéger-Máté M., Sipos B.Z. \& Hegedús A. (2002): A feketebodza (Sambucus nigra L.) beltartalmi értékeinek és antioxidáns hatásának változása az érés folyamán. Olaj, Szappan, Kozmetika. 53 (1): 33-36.

Stoll K. \& Gremminger U. (1986): Besondere Obstarten. Stuttgart. Eugen Ulmer Verlag

Szabó N., Sipos B.Z. \& Stefanovits-Bányai É. (2004): Antioxidant capacity, C-vitamin and anthocyanin content in the fruits of elderberry (Sambucus nigra L.) types. International Journal of Horticultural Science. 10(3): 77-79.

Szalay L. \& Halmágyi L. (1998): Gyógyító mézek és mézelố gyógynövények. Magyar Méhészek Egyesülete, Budapest.

Tátraházi R. (2002): Vadon termổ gyümölcsök táplálkozásbiológiai értékelése. Diplomamunka, Szent István Egyetem Élelmezéstudományi Kar, Budapest. 